\title{
IDENTIFICATION AND STUDY OF FISH SPECIES IN KARKHEH RIVER (IRAN)
}

\section{Zahra KHOSHNOOD *}

* Islamic Azad University, Faculty of Science, Department of Experimental Sciences, University Boulevard, Dezful, Iran, P. O. Box 313, IR-64618-57518, ZKhoshnood@gmail.com

DOI: 10.1515/trser-2015-0018

KEYWORDS: Iran, Karkheh River, fish identification, biodiversity.

\section{ABSTRACT}

For the investigation of fish from Karkheh River, sampling was performed in a six month period from August 2014 to January 2015. All sampled fish were measured for biometrical values (length and weight). General results of the sampling and identification of the fish showed the presence of 14 species from four fish families of Cyprinidae, Mugilidae, Siluridae and Macrostomidae, out of which the Cyprinidae family were the most frequent of the sampled fish. The most significant abundance belongs to Cyprinus carpio. The fish sampled in the present study were: Liza abu, Ctenopharyngodon idella, Barbel sp., Cyprinion macrostomum, Barbus sharpeyi, Hypophthalmichthys molitrix, Barbus esocinus, Barbus barbulus, Barbus luteus, Barbus grypus, Cyprinus carpio, Silurus triostegus, Mastacembelus circumcinctus and Capoeta trutta. Shannon Index results showed that the fish biodiversity in the studyed area followed a uniform path and additionally that the considered area at the studied period has good fish biodiversity.

RESUMEN: Identificación y estudio de especies ícticas en el Río Karkheh (Irán).

Con el fin de estudiar los peces del Río Karkheh, se realizaron muestreos a lo largo de un semestre, de agosto de 2011 a enero de 2015. Se tomaron medidas biométricas (peso y talla) de todos los peces colectados. Se identificaron 14 especies pertenecientes a cuatro familias: Cyprinidae, Mugilidae, Siluridae y Macrostomidae, siendo la familia Cyprinidae la más común en los muestreos. La especie Cyprinus carpio fue la más abundante. Las especies identidicadas en este estudio fueron: Liza abu, Ctenopharyngodon idella, Barbel sp., Cyprinion macrostomum, Barbus sharpeyi, Hypophthalmichthys molitrix, Barbus esocinus, Barbus barbulus, Barbus luteus, Barbus grypus, Cyprinus carpio, Silurus triostegus, Mastacembelus circumcinctus y Capoeta trutta. Tras aplicar el índice de Shannon, se evidencia que la biodiversidad es uniforme y que ésta, al momento y lugar de la colecta, es comparativamente alta.

REZUMAT: Identificarea și studiul speciilor de pești din râul Karkheh (Iran).

Pentru investigarea peștilor din râul Karkheh s-au prelevat probe de-a lungul a șase luni începând din august 2014 și până în ianuarie 2015. Toți peștii colectaţi au fost măsurați în lungime și cântăriți. Rezultatele generale din urma prelevării și identificării peștilor au arătat existența a 14 specii aparținând a patru familii: Cyprinidae, Mugilidae, Siluridae și Macrostomidae, dintre care familia Cyprinidae a avut frecvența cea mai mare în probele colectate. Specia cu cea mai mare abundență a fost Cyprinus carpio. Speciile de pești prelevate în acest studiu au fost: Liza abu, Ctenopharyngodon idella, Barbel sp., Cyprinion macrostomum, Barbus sharpeyi, Hypophthalmichthys molitrix, Barbus esocinus, Barbus barbulus, Barbus luteus, Barbus grypus, Cyprinus carpio, Silurus triostegus, Mastacembelus circumcinctus și Capoeta trutta. Rezultatele testului Shannon au arătat faptul că biodiversitatea speciilor de pești din aria studiată respectă un model uniform și de asemenea faptul că această arie dispunea de o biodiversitate foarte bună în momentul prelevării probelor. 


\section{INTRODUCTION}

Fish species have the highest diversity among all vertebrates. Almost 24,618 species were identified and about 9,966 (40.48\%) of these fish species are freshwater fish (Nelson, 1984, 1994). The study of fish species in aquatic ecosystems is valuable due to different aspects of evolutionary studies such as: ecology, environmental protection, aquatic reservoirs management, stock assessment and requirements of fish species (Lagler et al., 1962).

Due to the increasing effects of environmental pollution and anthropogenic activities on aquatic ecosystems, the study of the inhabitant species in watershed management context is crucial for environmental protection (Curtean-Bănăduc et al., 2007).

In spite of the large size of Iran and the presence of enormous rivers, lakes, lagoons, bays and other water bodies, unfortunately little data is available for species of different freshwater ecosystems. Among the available data one could refer to Berg (1948, 1949), Vladykov (1964), Coad (1980, 1982, 1995), Armantrout (1980), and Saadati (1977).

The Karkheh River in Khuzestan province is one of the largest and most important rivers of Iran (Fig. 1). Due to the high water discharge and the flood receiving situation of this river, two dams were built on it called Karkheh 1 and Karkheh 2.

The Karkheh River (Figs. 1, 2, 3 and 4) is one of the rivers with large amounts of traditional fishing, fish being sold annually in regional markets. The building of the two dams on this river could also affect the fish community.

In order to understand the effects of environmental pollutants and anthropogenic activities on the aquatic life of this region, with the added effects of unauthorized catches (catch by unauthorized tools and catches during unauthorized seasons), and also to determine the status of fish species in this river, we carried out a fish identification and frequency analysis. Many of these fish species could be useful for proliferation in breeding facilities for economic and ornamental purposes. The aim of this study was to identify the fish species of the Karkheh River near these two dams over a six month period.

\section{MATERIAL AND METHODS}

For the study of fish species of the Karkheh River, after a site visit, three sampling sites were established (Tab. 1. and Fig. 2) and the fish catch was done using cast nets with different mesh sizes for catching fish of different dimensions.

Fish were sampled from August 2014 to January 2015. Biometrical parameters of sampled fish were measured with a biometrical ruler and digital scale. For identification of fish species the gross characteristics such as dorsal fin, body shape and others were used along with the atlas book of fresh water fishes of Iran.

Biodiversity was defined using Shannon index (Shannon and Wiener, 1963).

Table 1: Geographic coordinates of sampling sites.

\begin{tabular}{|c|c|c|}
\hline \multirow{2}{*}{$\begin{array}{c}\text { Sampling } \\
\text { site }\end{array}$} & \multicolumn{2}{|c|}{$\begin{array}{c}\text { Geographic } \\
\text { coordinates }\end{array}$} \\
\cline { 2 - 3 } & Latitude & Longitude \\
\hline Station 1 & 3651967.28 & 761807.69 \\
\hline Station 2 & 3639928.58 & 777819.51 \\
\hline Station 3 & 3638556.18 & 780641.95 \\
\hline
\end{tabular}




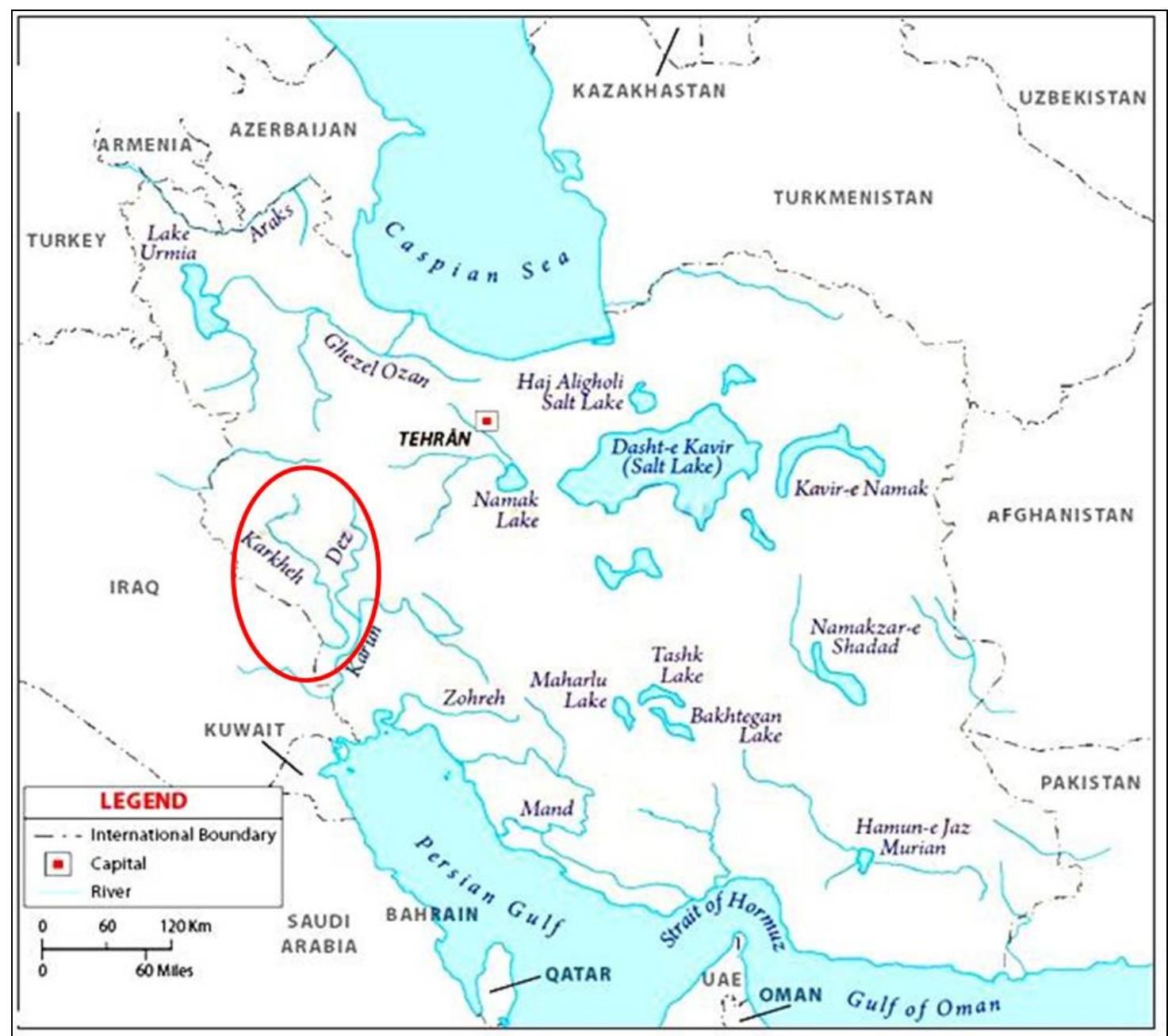

Figure 1: Iran's rivers and lakes map, the Karkheh River showed by the circle.

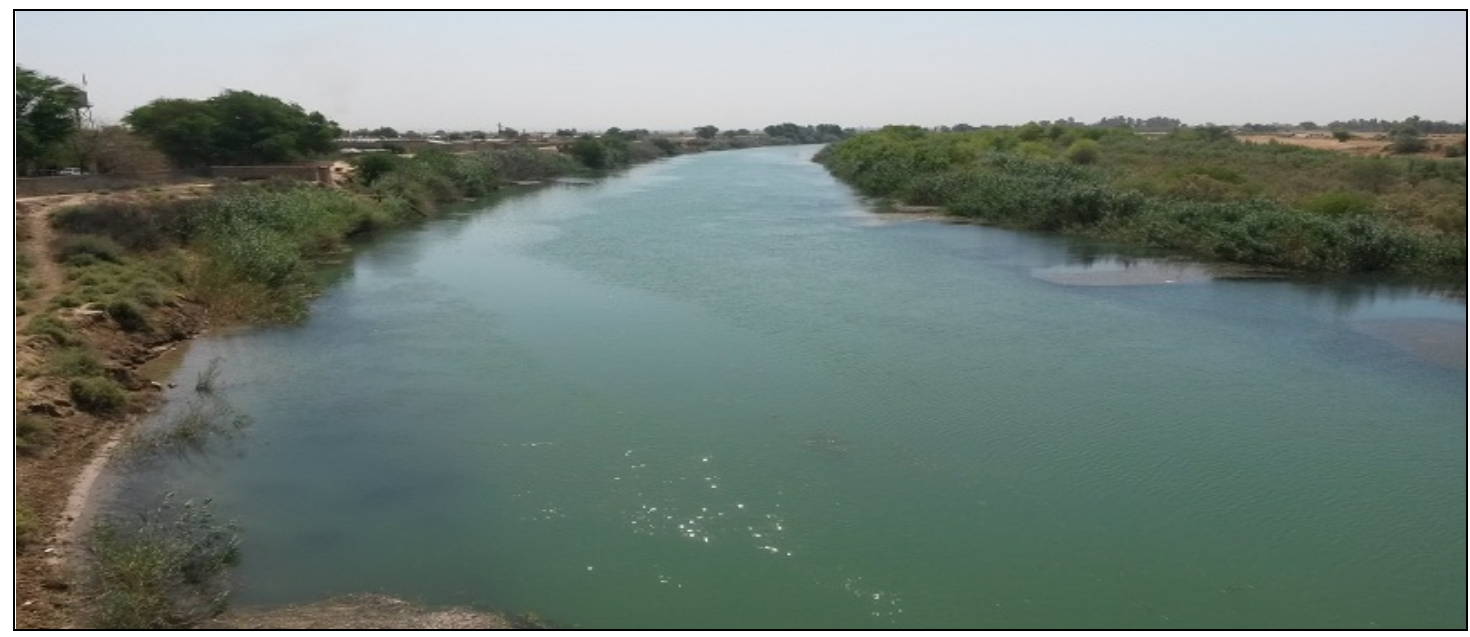

Figure 2: Karkheh River habitat in a plain sector. 


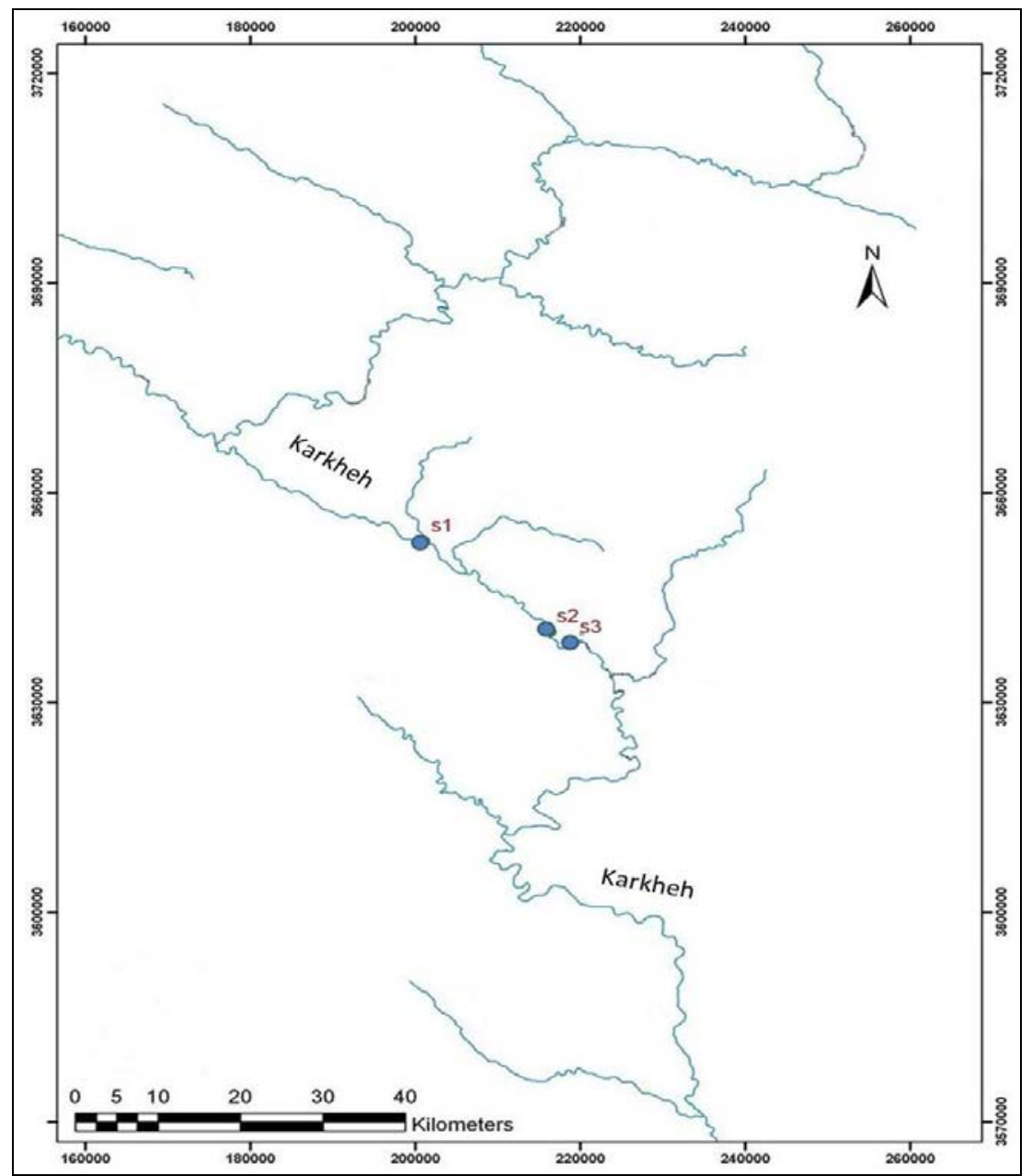

Figure 3: Karkeh River map with three sampling sites showed by blue circles (S1, S2 and S3).

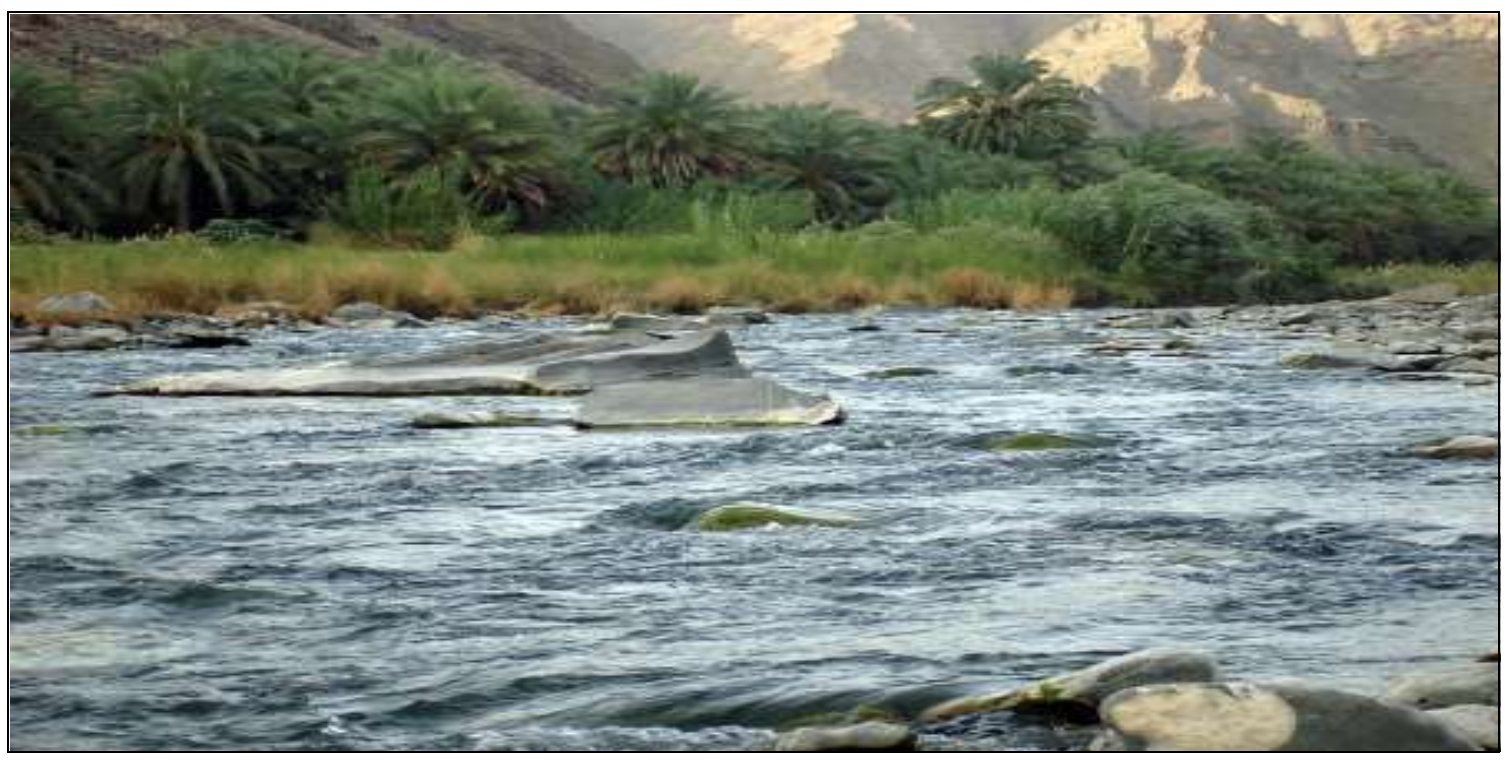

Figure 4: Karkheh River habitat in mountain sector. 


\section{RESULTS AND DISCUSSION}

Results of the sampling of fish species at all sampling sites over the six month period of the present study showed that sampled fish belong to four fish families including: Cyprinidae, Mugilidae, Siluridae and Macrostomidae. The most frequent fish species were representatives of the Cyprinidae family with: Cyprinus carpio, Barbus grypus, Barbus luteus, Barbus barbulus, Barbus esocinus, Hypophthalmichthys molitrix, Barbus sharpeyi, Cyprinion macrostomus, Ctenopharyngodon idella and Capoeta trutta. The identified fish species of Mugilidae, Siluridae and Macrostomidae families were Liza abu, Silurus triostegus and Mastacembelus circumcinctus respectively (Fig. 5).
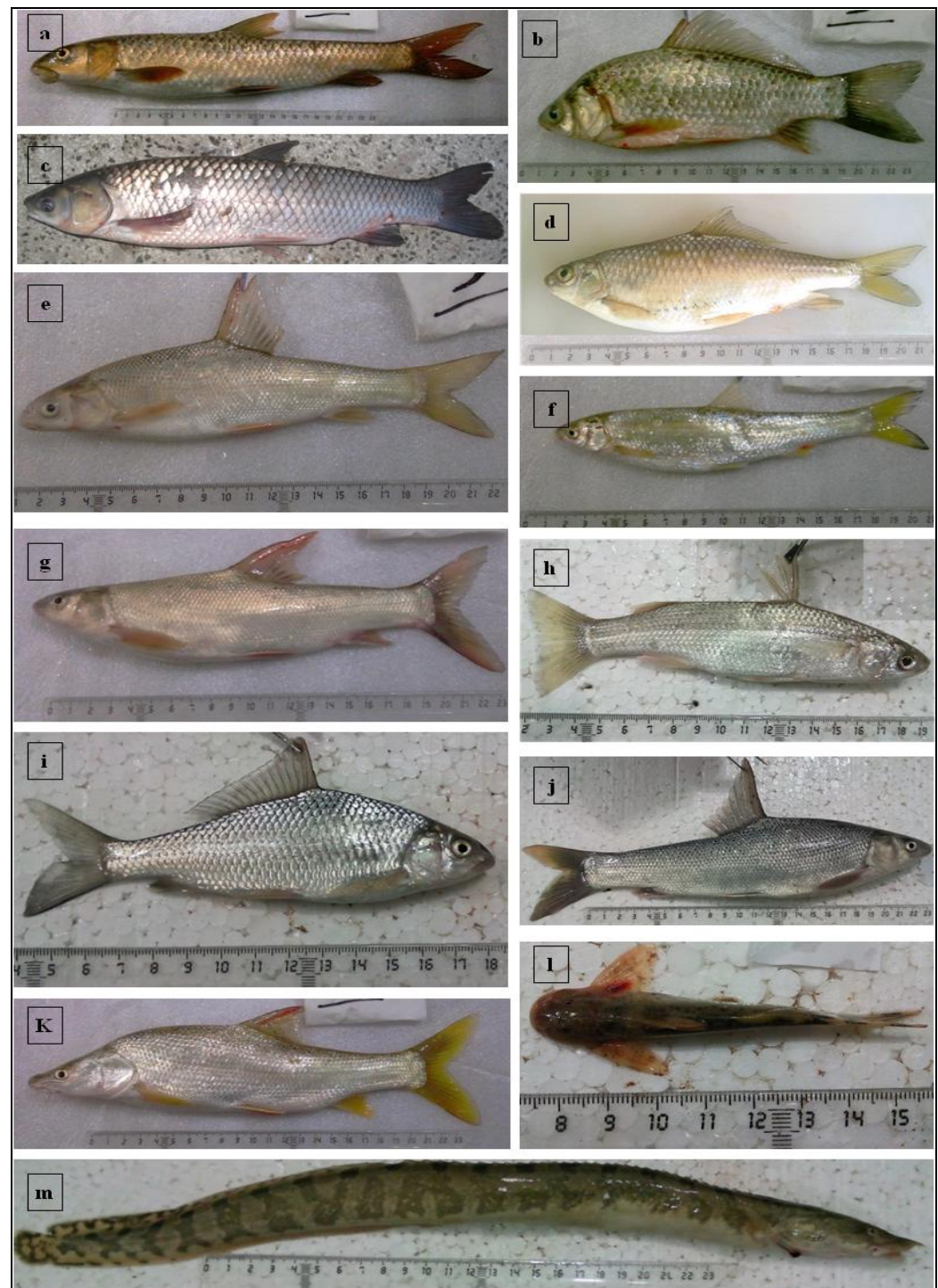

Figure 5: Fish species sampled from the Karkheh River, Iran. Barbus grypus (a); Cyprinus carpio (b); Ctenopharyngodon idella (c); Cyprinion macrostomus (d); Barbus esocinus (e); Barbel sp. (f); Hypophthalmichthys molitrix (g); Liza abu (h); Barbus sharpeyi (i); Capoeta trutta (j); Barbus sharpeyi (k); Silurus triostegus (l); Mastacembelus circumcinctus (m). 

figure 6.

Mean abundance results of sampled species from each sampling month are shown in

Results of the mean abundance of sampled species during the total six months of sampling showed that the species with the highest number of individuals in the Karkheh River was the common carp, Cyprinus carpio (Fig. 7).

Biodiversity results using Shannon index showed that the biodiversity of fish species of the Karkheh River was almost steady during the six months sampling period of the present study (Fig. 8).

Understanding the different components of the biosphere and various aspects of ecosystems is the first step for the management and protection of environment.

Accordingly, the study and the identification of animals and plants living in ecosystems are of special significance for the management of environmental resources.
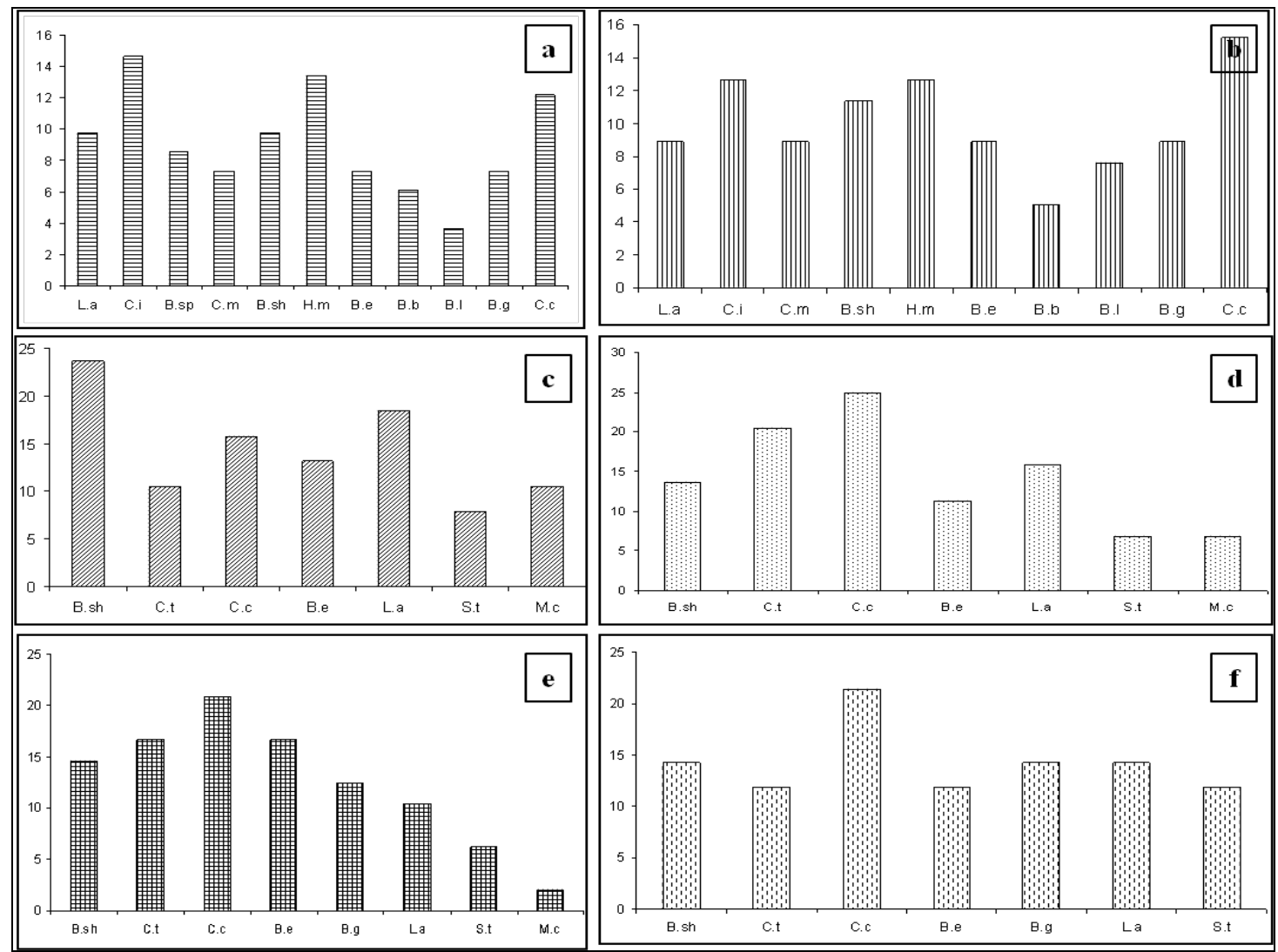

Figure 6: Abundance of sampled fish species in six month sampling period.

August (a); September (b); October (c); November (d); December (e); January (f). Abbreviations stand for species names: Liza abu, Ctenopharyngodon idella, Barbel sp., Cyprinion macrostomum, Barbus sharpeyi, Hypophthalmichthys molitrix, Barbus esocinus, Barbus barbulus, Barbus luteus, Barbus grypus, Cyprinus carpio, Silurus triostegus, Mastacembelus circumcinctus and Capoeta trutta. 


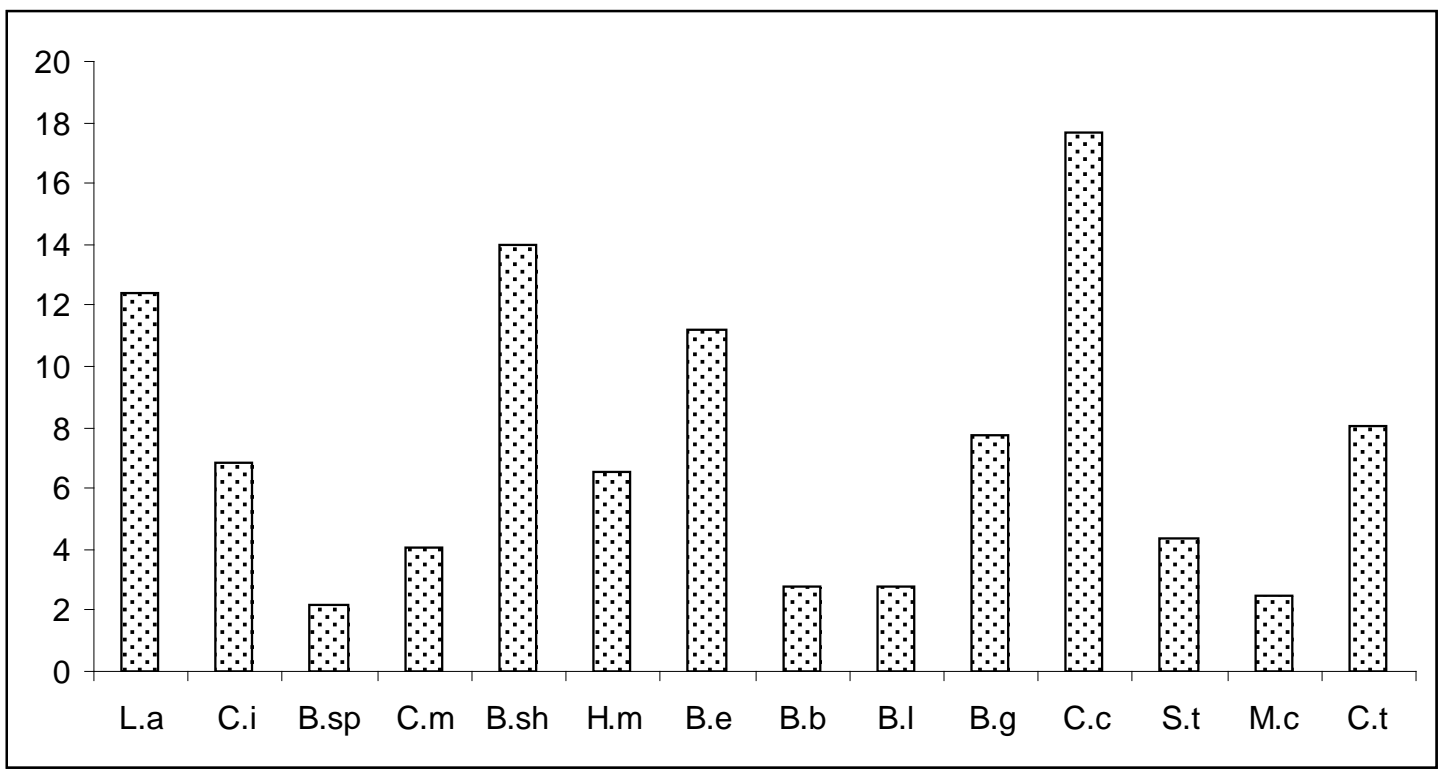

Figure 7: Total abundance of fish species during the six month period of study in the Karkheh River. The most abundant fish species during the study period was common carp, Cyprinus carpio. Abbreviations stand for species names: Liza abu, Ctenopharyngodon idella, Barbel sp., Cyprinion macrostomum, Barbus sharpeyi, Hypophthalmichthys molitrix, Barbus esocinus,

Barbus barbulus, Barbus luteus, Barbus grypus, Cyprinus carpio, Silurus triostegus, Mastacembelus circumcinctus and Capoeta trutta.

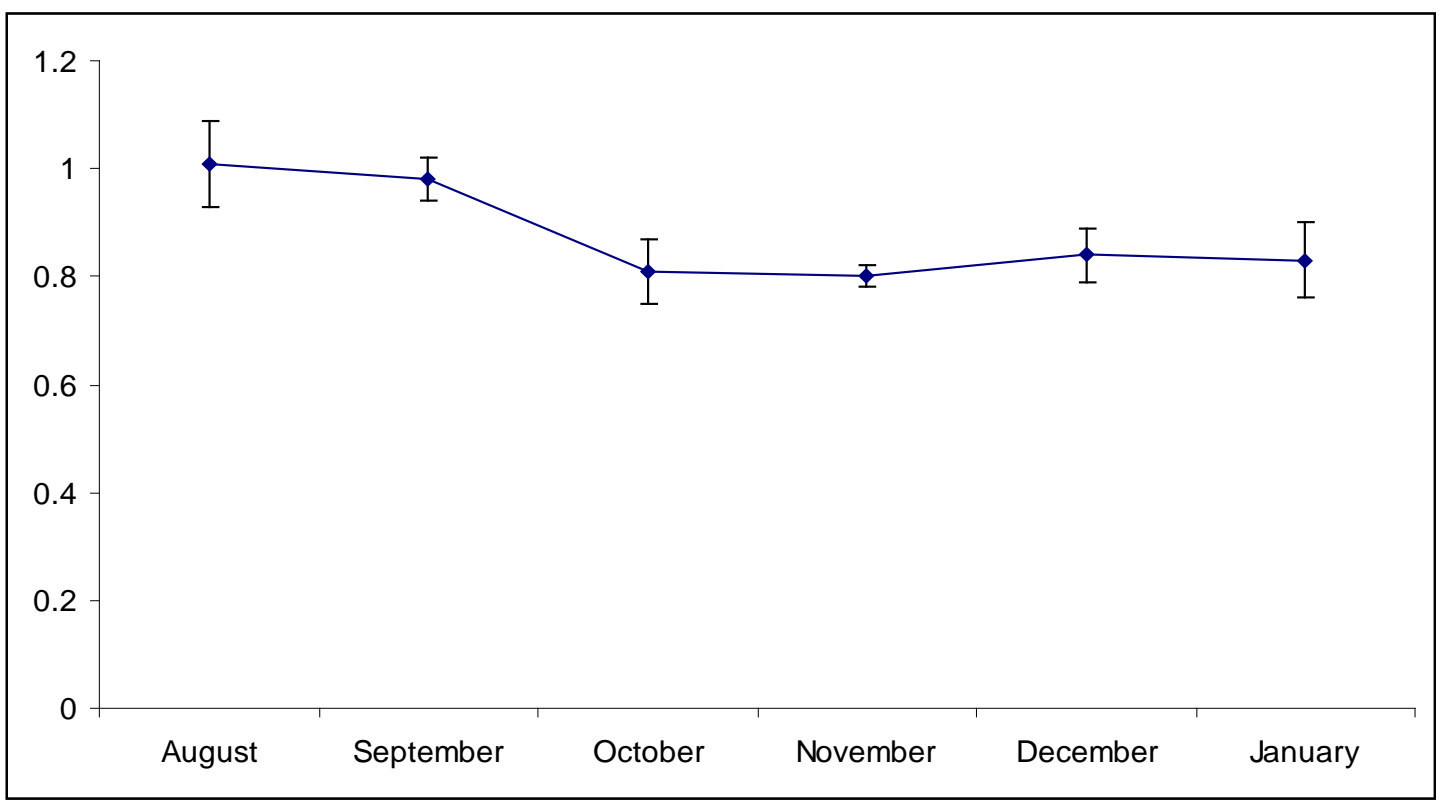

Figure 8: Shannon Index of the sampled species from the Karkheh River during the six months study period. 


\section{CONCLUSIONS}

According to the species identification, abundance and Shannon index. One could conclude that the Karkheh River in the studied area has a good biodiversity of freshwater fish during the sampling season. This would be a good reason for better environmental management and protection of this area for species conservation within this valuable ecosystem. 


\section{ACKNOWLEDGEMENTS}

The present study was supported by the grant from Dezful Branch, Islamic Azad University, Dezful, Iran, as an internal research project. 


\section{REFERENCES}

1. Armantrout N. B., 1980 - The freshwater fishes of Iran, PhD Thesis, Oregon Statein University, Corvallis, Oregon, 472.

2. Berg L. S., 1948 - Freshwater fishes of U.S.S.R. and adjacent countries, 1, Trady Institute Acad, Nauk U.S.S.R., 496.

3. Berg L. S., 1949 - Freshwater Fishes Of Iran and Adjacent Countries, Trudy, Zoology Icheskogo Instituta Academii Nauk U.S.S.R., 8, 783-858. (in Russian)

4. Coad B. W., 1980 - A Provisional Cheklist of the Freshwater Fishes of Iran, Journal of the Bombay Natural History Society, 76, 1, 86-105.

5. Coad B. W., 1982 - A new genus and species of Cichild endemic to Southern Iran, Copia, 1, 28-37.

6. Coad B. W., 1995 - The Freshwater Fishes of Iran, The academy of Science of The Czech Republic, Brno, 64.

7. Curtean-Bănăduc A., Bănăduc D. and Bucşa C., 2007 - Watershed Management - implications, risks, solutions, Strategies to Enhance Environmental Security in Transition Countries, NATO Security trough Science Series - C: Environmental Security, Springer, ISBN 978-1-4020-59957, 225-238.

8. Lagler K. F., Bardach J. E. and Miller R. R., 1962 - Ichthyology, John Wiley and Sons, New York, 545.

9. Nelson J. S., 1984 - Fishes of the World, 2th edition, A wiley interscience publication, Printed in the United States of America, 523.

10. Nelson J. S., 1994 - Fishes of the World, Third Edition, New York, John Wiley and Sons, Inc., 600 .

11. Saadati M. A. G., 1977 - Taxonomy and distribution of the freshwater fishes of Iran, M.S. Thesis, Colorado State University, Fort Collins, XIII, 212.

12. Shannon C. E. and Wiener W., 1963 -The Mathematical theory of communication, University of Juionis Press, Urbana, 117.

13. Vladykov V. D., 1964 - Report to the government of Iran on the inland fisheries, especially of the Caspian Sea with special reference to sturgeon, Food and Agriculture Organization, Rome, Report FAO/EPTA 1818, 51. 